\title{
Dakins Solution
}

National Cancer Institute

\section{Source}

National Cancer Institute. Dakins Solution. NCI Thesaurus. Code C28970.

A hig hly diluted solution of sodium hypochlorite $(0.5 \% \mathrm{w} / \mathrm{v})$ with topical anti-infective activity. Dakin's solution is used as an antiseptic to clean infected topical wounds. 